\title{
Evergreen Production System for Southern Highbush Blueberries in Florida'
}

\author{
Douglas A. Phillips, Jeffrey G. Williamson, and Patricio R. Munoz
}

\section{Introduction}

Southern highbush blueberries (SHB) are grown in two different production systems in Florida. In north-central and central Florida, SHB are primarily grown in a deciduous system, where the plants go dormant and defoliate during late fall or early winter. In this system, hydrogen cyanamide is often used to accelerate vegetative budbreak to support earlier flowering and fruit set and to concentrate the fruit ripening. In central and south-central Florida, many SHB are grown in an evergreen system, where the plants do not go dormant, and are managed to retain their leaves from the previous year through harvest the following spring in order to support early flowering and fruit set. The evergreen system has also been used under tunnels in north-central Florida. This publication provides an overview of the evergreen production system for SHB in Florida.

\section{Benefits}

The primary benefit of the evergreen production system is the ability for early fruit ripening and harvest on SHB varieties that are adapted to that system. Florida blueberry growers can produce fruit during an early market window (approximately March through May) during peak blueberry prices. Some SHB varieties adapted to the evergreen system can typically be harvested beginning early March, before SHB in the deciduous system can be harvested, although the evergreen system can experience a longer harvest season. In addition, varieties adapted to the evergreen system can be grown in south-central Florida, where many varieties adapted to the deciduous system could not be successfully grown due to mild winters with minimal chilling temperatures.

\section{Varieties}

Several cultivars developed by the UF/IFAS blueberry breeding program are adapted to the evergreen production system (see EDIS publication HS1245, Southern Highbush Blueberry Cultivars from the University of Florida, https:// edis.ifas.ufl.edu/hs1245, for more detailed information). These cultivars typically have early fruit maturity, good leaf retention, and perform well in central and south-central Florida's warmer winter temperatures. Choosing the proper cultivars for an evergreen system can be location- and farm-specific, and it requires careful research and planning on the part of the grower.

\section{Arcadia}

A very low-chill cultivar released by UF/IFAS in 2015. It has very high yield in evergreen management systems, with peak production in central and south-central Florida during the high-value market window. It has shown very good resistance to leaf diseases; however, it is susceptible to bacterial wilt (Ralstonia solanacearum). Arcadia can have an extended harvest season.

1. This document is HS1362, one of a series of the Horticultural Sciences Department, UF/IFAS Extension. Original publication date March 2020. Visit the EDIS website at https://edis.ifas.ufl.edu for the currently supported version of this publication.

2. Douglas A. Phillips, blueberry Extension coordinator; Jeffrey G. Williamson, professor; and Patricio R. Munoz, assistant professor, Horticultural Sciences Department; UF/IFAS Extension, Gainesville, FL 32611.

The Institute of Food and Agricultural Sciences (IFAS) is an Equal Opportunity Institution authorized to provide research, educational information and other services

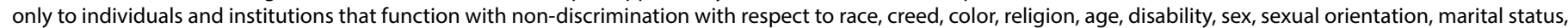

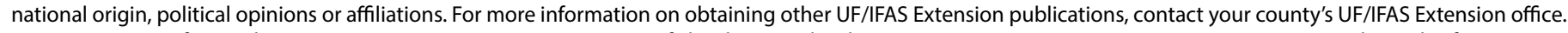
U.S. Department of Agriculture, UF/IFAS Extension Service, University of Florida, IFAS, Florida A \& M University Cooperative Extension Program, and Boards of County Commissioners Cooperating. Nick T. Place, dean for UF/IFAS Extension. 


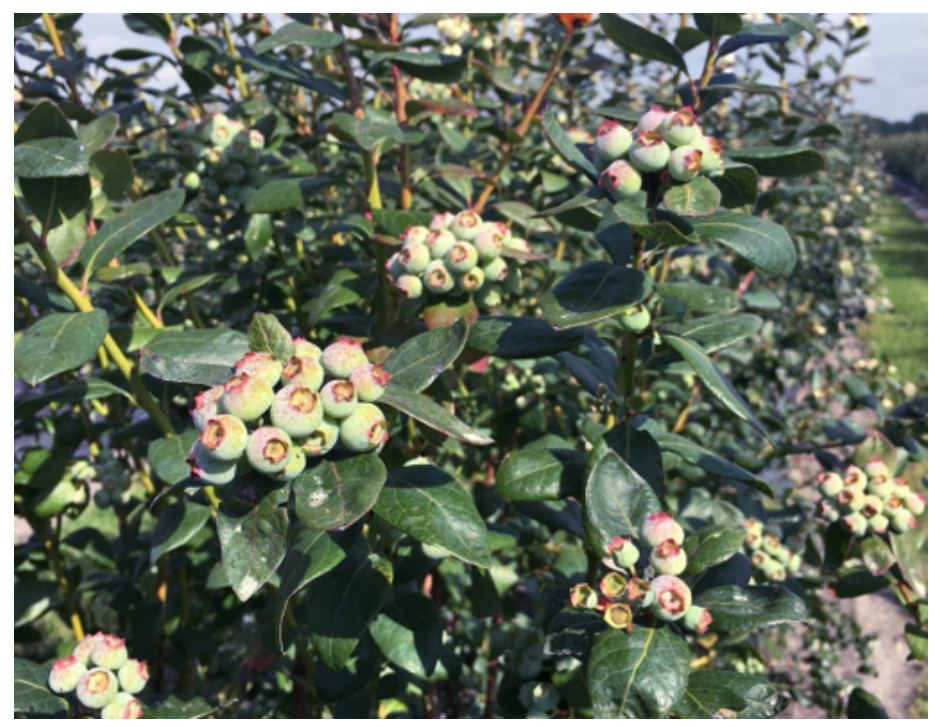

Figure 1. Arcadia.

Credits: D. Phillips, UF/IFAS

\section{Avanti}

A very early-ripening cultivar with a very low chill requirement, released by UF/IFAS in 2015 . Very sweet, flavorful berries and an above-average yield potential in the evergreen system. Avanti has shown some susceptibility to southern red mites and algal stem blotch.

\section{Chickadee}

A very early-ripening cultivar with a very low chilling requirement, released by UF/IFAS in 2009. The berry quality is maintained on the bush longer than most cultivars grown in Florida. However, due to its weak root system, it is prone to uprooting during strong storms. It does not respond well to heavy pruning and can have some susceptibility to leaf diseases.

\section{Endura}

A very low-chill, mid-to-late-season cultivar released by UF/IFAS in 2015. Endura can produce well under both evergreen and deciduous management systems. It has a high season-long yield that goes later into the harvest season.

\section{Kestrel}

A low-chill cultivar that blooms early and ripens very early, released by UF/IFAS in 2009. Kestrel has excellent fruit flavor. The berry detachment force is lower than average for blue fruit, which can result in loss of fruit following storms or windy conditions.

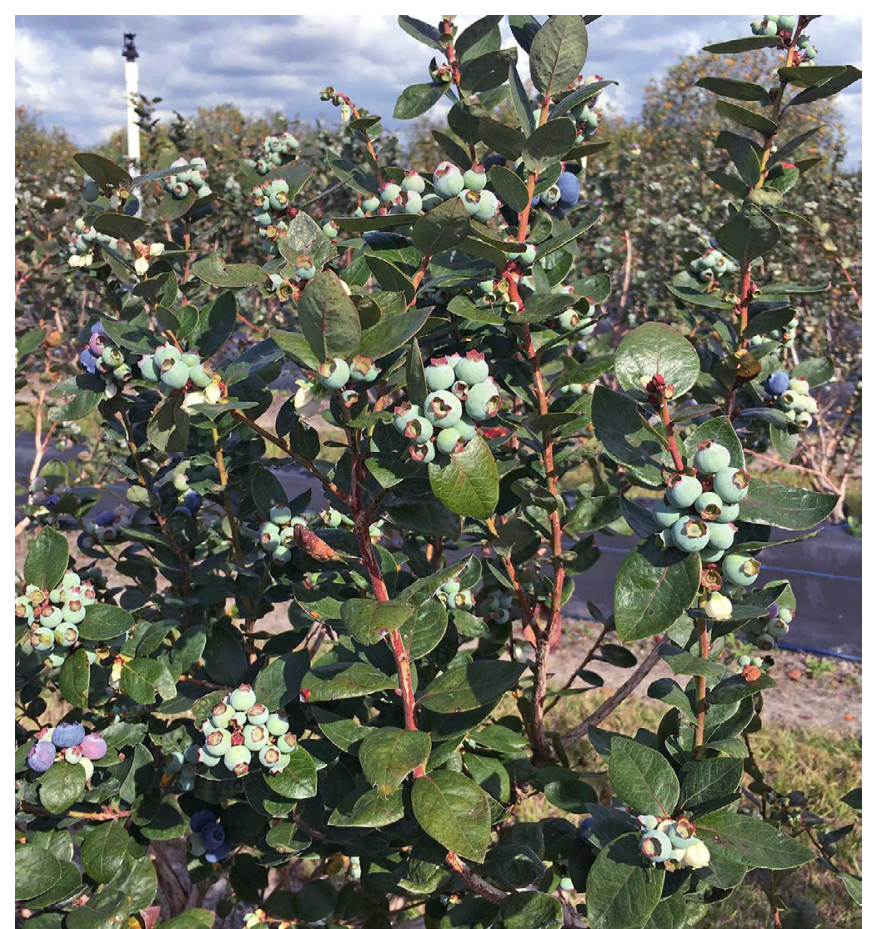

Figure 2. Kestrel.

Credits: D. Phillips, UF/IFAS

\section{Optimus}

An early-maturing cultivar with very high yield. Released by UF/IFAS in 2018, Optimus is suitable for machine harvest for the fresh market. The bush has good natural leafing and is suitable for both deciduous and evergreen production systems.

\section{Fertilization and Irrigation}

One of the key differences in the evergreen system is the need to continue fertilizing through fall and winter instead of cutting off fertilizer in early fall, which is frequently done under the deciduous system. Because a full plant canopy is maintained through the fall and winter in the evergreen system, sufficient nutrients (including nitrogen) must continue to be supplied in advance of plant needs. Some evergreen growers reduce the amount or change the ratios of fertilizer applied during late fall and winter months from the amounts used during summer. Currently, there are no published trials to support this practice. Leaf nutrient analysis, as well as a periodic soil nutrient analysis, should be performed to determine whether specific nutrients are in a sufficient range. Soil $\mathrm{pH}$ should be monitored regularly, because $\mathrm{pH}$ higher than the recommended range of 4.5-5.5 can make certain nutrients unavailable to the plant. These analyses, the seasonal period, and the stage of plant 
development can all assist growers with determining the amount and timing of fertilizer application.

Similar to fertilization, irrigation in an evergreen system will entail somewhat different practices than those used in a deciduous system. During fall and winter, plant transpiration and water use are higher in the evergreen system than with dormant plants, because deciduous SHB typically defoliate during this time. Providing sufficient irrigation during this time of reduced rainfall can help support healthy evergreen foliage.

Flower bud initiation in blueberries typically occurs in late summer to fall. Studies have shown that if there is defoliation during early fall, the number of flower buds may be reduced, resulting in lower yields. In order to promote good floral bud set, early fruit development, and early fruit ripening, the evergreen canopy must receive sufficient water and balanced nutrients appropriate for the season and growth stage of the plant.

\section{Disease Control}

Because it is essential that SHB in the evergreen system retain their leaves, it is important to control fungal leaf diseases during the hot, humid summers, early fall months, and mild winters of Florida. Several fungal diseases can lead to partial or full defoliation, resulting in poor plant health and reduced yields. These include anthracnose, Phyllosticta, rust, Septoria, and target spot (see EDIS publication PP348, Florida Blueberry Leaf Disease Guide, https://edis.ifas.ufl. edu/pp348). Use of recommended fungicides in a rotation with different modes of action, as well as proper cultural practices, will help keep these diseases under control (see EDIS publication HS1156, 2019 Florida Blueberry Integrated Pest Management Guide, https://edis.ifas.ufl.edu/hs380). Proper cultural practices include weed control to reduce alternate hosts for disease-causing pathogens and avoid competition for plant resources; removing and destroying leaf and stem debris; use of drip or microjet irrigation to minimize leaf wetness periods; and early-summer pruning to open the canopy and provide good air flow to promote foliage drying.

\section{Insect Control}

Proper insect pest control practices are also important to keep plants healthy through the following year's harvest. In particular, chilli thrips, flea beetles, gall midges, and southern red mites (as well as other mite species) can damage SHB foliage. Chilli thrips have piercing and sucking mouthparts, and mites have chelicerae that are modified for chewing and piercing and sucking the leaves, which remove sap and chlorophyll, respectively, from epidermal cells. Flea beetles have chewing mouthparts and feed on leaves, creating notches and shot holes. Gall midge larvae, which can create significant injury to floral buds, also feed on young developing leaf buds, which can damage and stunt new growth. Use of recommended insecticides in a rotation with different modes of action, along with proper cultural controls, will help to keep these pests under control (see EDIS publication HS1156, 2019 Florida Blueberry Integrated Pest Management Guide, https://edis.ifas.ufl.edu/hs380). Cultural controls include controlling weeds in and around production fields to reduce alternate hosts for insect pests, frequently scouting for insect damage, and early-summer pruning to open the canopy to allow for effective spray coverage.

\section{Summary}

The evergreen production system can be used to produce fruit very early in the market window in central and southcentral Florida. The keys to this system are the use of varieties that can maintain healthy leaves through the winter and perform well under warmer winter temperatures, avoidance of freezing temperatures that could induce dormancy, and certain modifications to management practices to keep the plant canopy strong and healthy. 